\title{
Indonesian Taxpayers' Compliance: A Meta-Analysis
}

\author{
Ardy $^{1}$, Ari Budi Kristanto ${ }^{1} \&$ Theresia Woro Damayanti ${ }^{1}$ \\ ${ }^{1}$ Faculty of Economics and Business, Satya Wacana Christian University, Indonesia \\ Correspondence: Ari Budi Kristanto, Faculty of Economics and Business, Satya Wacana Christian University, J1 \\ Diponegoro no 52-60 Salatiga Indonesia 50711. E-mail: ari.kristanto@ staff.uksw.edu
}

Received: April 8, 2018

Accepted: May 2, 2018

Online Published: May 10, 2018

doi:10.5430/afr.v7n3p29

URL: https://doi.org/10.5430/afr.v7n3p29

\begin{abstract}
This research examines the effect of six independent variables: tax socialization, tax knowledge, tax awareness, tax service quality, tax sanction, and tax audit, on the compliance of Indonesian taxpayers through a meta-analysis of previous researches on Indonesian taxpayers' compliance from 2006 to 2016. The purpose of this research is to strengthen the findings of previous research that the variables above affect Indonesian taxpayers' compliance. This research obtains empirical evidence that all of the variables above do affect Indonesian taxpayers' compliance. By using meta-analysis approach, it is concluded that tax socialization, tax knowledge, tax awareness, tax service quality, tax sanction, and tax audit have both positive and significant relationship either for individual or institutional tax payer's compliance. Theoretically, this research enriches the literature and gives a conclusion for previous researches about tax compliance in Indonesia, which results were varied. Practically, this research gives a clearer picture to the government about factors (tax socialization, tax knowledge, tax awareness, tax service quality, tax sanction, and tax audit) that could be improved to increase tax compliance.
\end{abstract}

Keywords: meta-analysis, taxpayers' compliance

\section{Introduction}

\subsection{Problem}

Tax compliance is a highly complex phenomenon when viewed from different perspectives, and in the taxation realm of Indonesia, often causes anxiety in the general society and taxpayers about paying their taxes (Hutagaol, 2007). Mustikasari (2007) stated that empirically, tax compliance in Indonesia is still low. It suggests that the low tax compliance hinders the efforts to increase the tax ratio in Indonesia (Nasution, 2009).

Various prior research has already found factors that affect taxpayers' compliance, which include tax socialization (Ananda, Kumadji, \& Husaini, 2015; Andyastuti, Topowijono, \& Husaini, 2013; Ariesta \& Suryaningsih, 2013; Ihsan, 2013; Meliala \& Inasius, 2015; Pamuji, Mukzam, \& Sudjana, 2014; Putra, Handayani, \& Topowijoyono., 2014; Rohmawati \& Rasmini, 2012; Sudrajat \& Ompusunggu, 2015), tax awareness (Doli \& Rusydi, 2014; Eddy \& Carolina, 2015; Kristanty, Khairani, \& Fajriana, 2014; Mir'atusholihah, Kumadji, \& Ismono, 2014; Pandan, 2014; Sudrajat \& Ompusunggu, 2015; Tampubolon \& Pratomo, 2015; Widorini \& Nugroho, 2014), tax service quality (Andyastuti et al., 2013; Ariesta \& Suryaningsih, 2013; Jatmiko, 2006; Kundalini, 2015; Kusuma, 2016; Mahardika, 2015; Pandan, 2014; Paramartha \& Rasmini, 2015; Puri, 2014; Rajif, 2012; Rohmawati \& Rasmini, 2012; Sandi, 2010; Widyastuti, 2015), tax sanction (Aprilina, Made, \& Dianawati, 2016; Dharma \& Ariyanto, 2014; Hantoyo, Kertahadi, \& Handayani, 2016; Kusuma, 2016; Putra et al., 2014; Tiraada, 2013; Widyastuti, 2015), and tax audit (Andyastuti et al., 2013; Anjarini, Prasetyo, \& Irani, 2012; Aprilina et al., 2016; Mandagi, Sabijono, \& Tirayoh, 2014; Pandan, 2014; Sukmawati, 2015) albeit with variable and different results. These differences will create an unnecessary difficulty to conclude the factors that affect taxpayers' compliance of fulfilling their tax duties.

Instead of using survey methods similar to prior research, this research uses a meta-analysis method on previous research. According to Cooper (1982), meta-analysis is a statistical technique that combines data from previous similar researches, to create a synthesized result. The purpose of a meta-analysis is to integrate existing research.

\subsection{Introduce the Problem}

This meta-analysis research focuses on independent variables that are studied at least 3 times in previous researches whose results are consistent both for individual and institutional taxpayers (Eny, Subroto, Sutrisno, \& Irianto, 2015). These independent variables are tax socialization, tax knowledge, tax awareness, tax service quality, tax sanction, 
and tax audit.

\subsection{Effect of Tax Socialization on Tax Compliance}

Tax socialization, according to Ananda et al. (2015), is an effort done by the "Direktorat Jenderal Pajak" (Directorate General of Taxes of Indonesia, hereafter DGT) to provide information and guidance about everything related to taxation. Good and understandable socialization programs are assumed to increase taxpayers' motivation in fulfilling their tax duties. This opinion is in line with Sudrajat and Ompusunggu (2015) that one of the factors that can be emphasized by the officers in increasing tax compliance is tax socialization through communal counselings, moral appeals in the forms of billboards and posters, and taxation websites that are accessible to taxpayers.

Meliala and Inasius (2015), Sudrajat and Ompusunggu (2015), Putra et al. (2014), Andyastuti et al. (2013), Ariesta and Suryaningsih (2013), Pamuji et al. (2014), Rohmawati and Rasmini (2012), and Ihsan (2013), stated in their researches that socialization has a positive effect on tax compliance. This argument may be formulated as:

H1. Tax socialization has a positive relationship on tax compliance

\subsection{Effect of Tax Knowledge on Tax Compliance}

Adequate taxpayers' knowledge, according to Ghoni (2012), consisting of knowledge on general concepts of taxation, types of taxes that apply in Indonesia ranges from tax subjects, tax objects, tax tariffs, calculation of tax payable, recording of tax payable, and knowledge of filling the tax report form. This knowledge is not limited to conceptual understanding based on Law on General Provisions \& Tax Procedures (Undang-Undang Perpajakan), Minister of Finances' Decree (Keputusan Menteri Keuangan), Circular Letter (Surat Edaran) and Ministerial Decree (Surat Keputusan) but also includes the technical ability to calculate the sum of tax payable (Supriyati, 2012). Taxpayers with such knowledge have a higher tendency to fulfill their tax duties. According to Nugroho (2012), such knowledge correlates with the taxpayers' ability to behave by taxation policies. Conversely, taxpayers without such knowledge may not be able to behave appropriately. Therefore, taxpayers' knowledge on taxation affects whether or not the taxpayers will fulfill their tax duties.

Previous research showed that tax knowledge has a positive effect on tax compliance (Doli \& Rusydi, 2014; Dyah, Handayani, \& Sulasmiyati, 2015; Eddy \& Carolina, 2015; Ihsan, 2013; Kristanty et al., 2014; Mir'atusholihah et al., 2014; Pandan, 2014; Paramartha \& Rasmini, 2015; Sudrajat \& Ompusunggu, 2015; Tampubolon \& Pratomo, 2015; Widorini \& Nugroho, 2014). This argument may be formulated as:

H2. Tax knowledge has a positive relationship on tax compliance

\subsection{Effect of Tax Awareness on Tax Compliance}

Taxpayers are said to be "aware" if they acknowledge the tax laws and provisions, tax's roles in funding the nation, and that tax duty must be conducted according to the provisions; understand the tax's roles on funding the nation; can calculate, pay and voluntarily report taxes (Asri \& Wuri., 2009). Soemarso (1998) also stated that public's low tax awareness is often one of the reasons why tax potential is unable to be reached. Lerche (1980) also argued that tax awareness often becomes an obstacle in collecting taxes from the public. This indicates that the lack of awareness is very likely to decrease tax compliance. Taxpayers' awareness in fulfilling their tax duties is necessary to increase tax compliance (Jatmiko, 2006).

Previous researches (Andinata, 2015; Doli \& Rusydi, 2014; Indriyani \& Sukartha, 2014; Jatmiko, 2006; Kundalini, 2015; Muliari \& Setiawan, 2011; Muzaki \& Kusbandiyah, 2014; Pandan, 2014; Puri, 2014; Putra et al., 2014; Rohmawati \& Rasmini, 2012; Santoso, Susilo, \& Sulasmiyati, 2015; Tiraada, 2013) showed that tax awareness has a positive effect on tax compliance. This argument may be formulated as:

H3. Tax awareness has a positive relationship on tax compliance

\subsection{Effect of Tax Service Quality on Tax Compliance}

According to Kotler (2005), service is defined as every action or activity that can be offered by an entity to the other, which is fundamentally intangible and does not affect any ownership. Thus, tax service is an activity provided by the "Kantor Pelayanan Pajak" (Tax Office) to satisfy taxpayers. Junita and Widiastuti (2008) stated that service quality is expected level of competitiveness and the control of such competitiveness is to satisfy customers' wants. Tax officers are expected to be competent, which in this context refers to their skill, knowledge, and experience in tax policies, administrations, and laws. Additionally, tax officers are also expected to have high motivation as public servants (Ilyas \& Burton, 2010). According to Risnawati (2009), DGT needs to increase tax service quality so that it complies with the tax laws to support taxpayers' compliance of fulfilling their tax duties, helps to reach the government's goal 
to carry out national development and assures a financially stable government. Through DGT's Circular Letter number SE-84/PJ/2011 on Prime Service, several provisions to increase service quality provided by tax officers to taxpayers are confirmed.

Andyastuti et al. (2013), Kundalini (2015), Sandi (2010), Puri (2014), Rajif (2012), Jatmiko (2006), Kusuma (2016), Widyastuti (2015), Pandan (2014), Ariesta and Suryaningsih (2013), Rohmawati and Rasmini (2012), Mahardika (2015), Paramartha and Rasmini (2015), Sukmawati (2015), Ihsan (2013), and Dyah et al. (2015) had empirically proven that tax service quality has a positive effect on tax compliance. This argument may be formulated as:

H4. Tax service quality has a positive effect on tax compliance

\subsection{Effect of Tax Sanction on Tax Compliance}

In general, laws and provisions regulate people's rights and obligations, as well as permissible and prohibited actions. For those laws and provisions to be obeyed, there must be sanctions for the offenders, and so are the case in tax laws (Suyatmin, 2004). In taxation laws, there are two types of sanction: administrative and criminal sanctions. Administrative sanction is applicable if taxpayers violate their duties as in Law number 28 the Year 2007 on General Provisions and Taxation Procedures. Administrative sanction includes the administration of interests, fines, and tax increases. On the other hand, criminal sanction includes imprisonment (Rahayu, 2010). Tax sanction is a guarantee that the provisions in tax laws would be obeyed; therefore it is a way to prevent violations of taxation norms (Mardiasmo, 2003). Taxpayers will fulfill their tax duties if they view that the tax sanction applied upon violation is a severe harm. Moreover, Faisal (2009) stated that even though tax sanctions could potentially provide national income, the primary motivation to apply sanctions is to keep taxpayers fulfilling their tax duties.

Previous researches by Tiraada (2013), Ngadiman and Huslin (2015), Dharma and Ariyanto (2014), Hantoyo et al. (2016), Pujiwidodo (2016), Rajif (2012), Jatmiko (2006), Utami and Kardinal (2013), Kusuma (2016), Widyastuti (2015), Putra et al. (2014), Muliari and Setiawan (2011), Andyastuti et al. (2013), Rohmawati and Rasmini (2012), Aprilina et al. (2016), Santoso et al. (2015), Ariesta and Suryaningsih (2013), Indriyani and Sukartha (2014), Doli and Rusydi (2014), Suyapto and Lasmana (2014), Muzaki and Kusbandiyah (2014), Warouw, Sondakh, and Walandouw (2015), Paramartha and Rasmini (2015) showed that tax sanction has a positive effect on tax compliance. This argument may be formulated as:

H5. Tax sanction has a positive relationship on tax compliance.

\subsection{Effect of Tax Audit on Tax Compliance}

Based on article 1 clause (25) on Law number 28 Year 2007 on General Provisions and Taxation Procedures, tax audit is a sequence of activities in collecting and processing data, information and/or evidence that are conducted in an objective and professional way based on an audit standard to test tax compliance and/or other purposes in accordance with the tax laws. Such tax audit is expected to increase taxpayers' compliance in fulfilling their duties. Audit findings are considered to be both a precious experience for tax officers, and a part of the taxpayers' learning curve, so that they may not repeat the same mistake in fulfilling their tax duties (Hutagaol, 2007).

Pandan (2014), Andyastuti et al. (2013), Anjarini et al. (2012), Aprilina et al. (2016), Mandagi et al. (2014), Suyapto and Lasmana (2014), Ginting (2015), Ihsan (2013), Sukmawati (2015) had empirically proven that tax tax audit has a positive effect on tax compliance. This argument may be formulated as:

H6. Tax audit has a positive relationship on tax compliance

\section{Method}

This research uses meta-analysis to combine statistically previous research in obtaining a quantitative synthesis. This research analyzes previous research on individual and institutional tax compliance in Indonesia from 2006 to 2016. Secondary data in the form of research articles on tax compliance, published in Indonesia and accessible, are used.

Researches that are included in the meta-analysis all fulfill these criteria: (1) quantitative research about factors that affect individual and institutional taxpayers' compliance; (2) independent variables that are included in the analysis appeared at least three times in all research (Eny et al., 2015); (3) research that studied about individual and institutional taxpayers' compliance as the dependent variable.

Data analysis is done quantitatively using meta-analysis method. The analysis procedure follows Fanani (2014). Relevant statistical reports of each study are transformed into an effect size to be compared and integrated, assuming that the values used are statistical independence. Values of statistical test results in previous studies are converted into $r$ statistic using Lyons (1998) equation. After the $r$ statistic values are obtained from each research sample, 
Hunter and Schmidt (1990) argued that three further steps need to be done.

1. The first step is to calculate the mean population correlation (r) from the weighted correlation coefficient average $(\mathrm{r} \overline{)}$ with sample size $(\mathrm{Ni})$ obtained from total researches reviewed.

$$
\mathrm{r}=\frac{\sum(\mathrm{Ni} \mathrm{ri})}{\sum \mathrm{Ni}}
$$

2. The second step is to calculate the observed variance (sr) from all correlation coefficients in selected research samples by using average square error weighted divided by the number of samples.

$$
\mathrm{r}=\frac{\sum\left[\mathrm{Ni}(\mathrm{ri}-\overline{\mathrm{r}})^{2}\right]}{\sum \mathrm{Ni}}
$$

3. The third step is to estimate the sampling error variance.

$$
\mathrm{Se}=\frac{\left(1-\overline{\mathrm{r}}^{2}\right)^{2} \mathrm{~K}}{\sum \mathrm{Ni}}
$$

In this equation, $\mathrm{K}$ is the number of each study included in the analysis. The estimated sampling error variance is then subtracted from the observed variance, thus leaving residual variance which gives the unbiased estimation of population variance.

$$
S p=S r-S e
$$

4. The next step is to determine the confidence interval percentage level. Since the sample size in this research exceeds 30 , then the $\mathrm{Z}$ statistic can be calculated as follows.

$$
r-(\operatorname{Sp} \times 1,96), \quad r+(\operatorname{Sp} \times 1,96)
$$

To test statistical validity, Hunter and Schmidt's (1990) equation are used.

$$
\mathrm{X}_{\mathrm{k}-1}^{2}=\frac{\mathrm{N}_{\mathrm{S}_{\mathrm{r}}^{2}}}{\left(1-\bar{r}^{2}\right)^{2}}=\mathrm{K} \frac{\mathrm{S}_{\mathrm{r}}^{2}}{\mathrm{~S}_{\mathrm{e}}^{2}}
$$

The relationship between the studied variables will become unmoderated, if the statistics show insignificant results, usually larger than $X_{k-1,0.05}^{2}$, which indicates that meta-analysis subgroup test is needed. This is done to determine a new confidence interval which decreases heterogeneity level caused by the use of proxy in the various types of variables. The sub-group meta-analysis gives a better picture of the studied subject than global meta-analysis (Fanani, 2014). Since the measurement of the dependent variable (tax compliance) only uses one proxy, this equation is unnecessary.

The hypothesis is tested with Direct Hypothesis Test, following García-Meca and Sánchez-Ballesta (2009) method.

1. This research analyzes the relationship between each independent variable and the dependent variable. When the average correlation's value lies between the minimum and the maximum confidence interval, regardless whether the values are all positive or negative, then the relationship is significant. If one value is negative while the other is positive (and vice versa), then the average correlation is insignificant.

2. If the average correlation shows a positive value and the confidence interval is significant, then the relationship is positive so that the hypothesis should be accepted. The opposite condition rejects the hypothesis.

\section{Results}

\subsection{Data and Result}

This research uses a purposive sampling method to obtain representative samples according to the criteria determined and shown in table 1 . 
Table 1. Sampling Criteria

\begin{tabular}{clc}
\hline Number & \multicolumn{1}{c}{ Sampling Criteria } & Quantity \\
\hline 1. & Articles on tax compliance in Indonesia, based on Google Scholar search, between & 70 \\
& $2006-2016$ & 6 \\
2. & Inaccessible articles & 3 \\
3. & Articles with less than three independent variables that appear in every relevant research & 4 \\
4. & Articles that do not provide statistic values needed & 57 \\
\hline
\end{tabular}

There are 57 relevant research articles and able to fulfill the criteria. Variables that become the research subject are variables that were studied and reported by at least three research, each for the individual and institutional taxpayer. Research used as samples were done between 2006 and 2016. The results of global meta-analysis for the relationship of explanatory variable and individual and institutional taxpayers' compliance in Indonesia are explained below.

Table 2. Hypothesis Testing- Meta Analisis

\begin{tabular}{lccccccc}
\hline \multicolumn{1}{c}{ ExplanatoryVariable } & $\mathrm{N}$ & Studies & $\mathrm{r}$ & $\mathrm{Sr}$ & $\mathrm{Se}$ & $\mathrm{Sp}$ & 95\% Confidence \\
\hline Tax Socialization & 1545 & 11 & $0,274^{*}$ & 0,025 & 0,006 & 0,019 & $0,235-0,313$ \\
Tax Knowledge & 1894 & 15 & $0,316^{*}$ & 0,044 & 0,006 & 0,037 & $0,242-0,390$ \\
Tax Awareness & 1383 & 16 & $0,374^{*}$ & 0,0299 & 0,0085 & 0,021 & $0,332-0,416$ \\
Tax service quality & 2668 & 26 & $0,297^{*}$ & 0,042 & 0,008 & 0,034 & $0,229-0,366$ \\
Tax Saction & 3170 & 28 & $0,311^{*}$ & 0,032 & 0,0072 & 0,024 & $0,262-0,360$ \\
Tax Audit & 1455 & 11 & $0,239^{*}$ & 0,021 & 0,0067 & 0,0143 & $0,211-0,267$ \\
\hline
\end{tabular}

On table 2, tax socialization variable has a positive and significant relationship with tax compliance, proven by the $\mathrm{r}$ value which lies in between the confidence interval. The meta-analysis results of tax knowledge variable give empirical evidence that tax knowledge has a positive and significant relationship with tax compliance; therefore hypothesis 2 is accepted. Higher taxpayers' knowledge on taxation correlates with higher levels of tax compliance. Hypothesis 3 , which states that tax awareness has a positive relationship with tax compliance, is accepted. Higher tax awareness correlates with higher levels of tax compliance. Tax service quality variable also has a positive and significant relationship with tax compliance; therefore hypothesis 4 is accepted. Better service quality provided by tax officers correlates with higher levels of tax compliance.

Meta-analysis of tax sanction variable gets some empirical evidence which supports hypothesis 5 . Tax sanction has a positive and significant relationship with tax compliance. The meta-analysis results of tax audit variable show that it has a positive relationship with tax compliance, which shows that tax audit could improve tax compliance. Therefore, hypothesis 6 is accepted.

Table 3 shows the tax compliance meta-analysis results if separated into individual and institutional tax compliance. Meta-analysis shows that all 6 variables have both positive and significant relationship with individual tax compliance. 
Table 3. Meta Analysis Individual Tax Payer and Institutional Tax Payer

\begin{tabular}{|c|c|c|c|c|c|c|}
\hline \multirow[t]{2}{*}{ Explanatory Variable } & \multicolumn{5}{|c|}{ Interval } & $\begin{array}{c}95 \% \text { Confidence } \\
\text { Interval }\end{array}$ \\
\hline & \multicolumn{3}{|c|}{ Individual Tax Payer } & \multicolumn{3}{|c|}{ Institutional Tax Payer } \\
\hline Tax Socialization & 8 & $0,301 *$ & $0,279-0,324$ & 3 & $0,179 *$ & $0,169-0,189$ \\
\hline Tax Knowledge & 8 & $0,364 *$ & $0,287-0,44$ & 7 & $0,265 *$ & $0,204-0,326$ \\
\hline Tax Awareness & 13 & $0,365^{*}$ & $0,313-0,417$ & 3 & 0,420 & $0,437-0,404$ \\
\hline Tax service quality & 20 & $0,307 *$ & $0,225-0,338$ & 6 & $0,275^{*}$ & $0,239-0,312$ \\
\hline Tax Saction & 21 & $0,319 *$ & $0,270-0,369$ & 7 & $0,276^{*}$ & $0,233-0,320$ \\
\hline Tax Audit & 4 & $0,177^{*}$ & $0,147-0,206$ & 7 & $0,277 *$ & $0,257-0,297$ \\
\hline
\end{tabular}

On the other hand, all variables, except tax awareness variable (which shows no significant relationship), have both positive and significant relationship with institutional tax compliance.

\section{Discussion}

Changes in taxation laws force DGT to do tax socialization and help the public understand the new taxation laws. Tax socialization is expected to increase all taxpayers' understanding and knowledge, as well as their awareness in paying and reporting taxes. Hypothesis test on tax socialization and tax compliance gave positive and significant results. If the test is done separately for individual and institutional taxpayers, the relationship is still positive and significant for both tests.

Generally, tax socialization could increase the number of taxpayers and their tax compliance. The government must be able to show that the tax funds are used for public needs (Herryanto \& Toly, 2013). With tax socialization, effective participation of the public in fulfilling their rights and obligations as taxpayers are expected. Research done by Putra et al. (2014), Andyastuti et al. (2013), Ariesta and Suryaningsih (2013), and Pamuji et al. (2014) stated that tax socialization has a positive relationship with tax compliance.

Taxpayers' knowledge affects their tax compliance. The self-assessment system in Indonesia dictates that taxpayers must completely understand about fulfilling their tax duties. Meta-analysis of tax knowledge variable gave positive and significant results. When the test is done separately for individual and institutional taxpayers, the outcome is still positive and significant for both tests. This is supported by Nugroho (2012) opinion that taxpayers with higher tax knowledge can behave better by the tax provisions.

Tax awareness is a condition where taxpayers understand, acknowledge, appreciate, and comply with tax provisions as well as having the competence and will to fulfill their tax duties. Generally, tax awareness has a positive and significant relationship with both individual and institutional tax compliance. Tax awareness relates to taxpayers' perception and affects their behavior. Taxpayers with better awareness behave more appropriately by the tax provisions, so they have the will to fulfill their tax duties.

But when the meta-analysis on tax awareness is separated for individual and institutional taxpayers, the result shows that tax awareness has no significant relationship with institutional tax compliance. This may relate to institutional taxpayers' higher complexity: their Annual Tax Return reports (Surat Pemberitahuan Tahunan) and larger sums of tax may cause them to tend to exploit tax law loopholes or even disobey the tax laws.

The success of tax collecting does not depend only on the taxpayer only, but also depends on the tax service quality provided by DGT. Hypothesis testing on tax service quality shows a positive and significant relationship with both individual and institutional taxpayers. So does the separated meta-analysis. Previous research also shows that tax service quality has a positive and significant relationship with tax compliance (Andyastuti et al., 2013; Ariesta \& Suryaningsih, 2013; Dyah et al., 2015; Mahardika, 2015; Pandan, 2014; Paramartha \& Rasmini, 2015; Rohmawati \& Rasmini, 2012; Sukmawati, 2015).

The level of tax compliance is also affected by tax sanctions. Tax sanction is a preventive measure of the violation of taxation norms (Mardiasmo, 2003). Hypothesis testing on tax sanction shows a positive and significant relationship with both individual and institutional tax compliance. Taxpayers will fulfill their tax duties if they view that the tax sanction applied upon violation is a severe harm (Fraternesi, 2001). The higher the tax payable, the harder it is for the taxpayers to pay them. Even though taxpayers are not rewarded for their compliance, they would be punished if they neglect to pay taxes, or are deliberately not fulfilling their tax duties (Jatmiko, 2006). 
One of DGT's efforts to monitor the tax self-assessment system is tax audit. Meta-analysis shows that tax audit has a positive and significant relationship with both individual and institutional tax compliance. The separated analysis also gives the same results: tax audit has a positive and significant relationship, either for individual or institutional tax payer's compliance. This is consistent with the 2015 tax audit (to support taxpayer counseling year), which showed that tax audit affects tax compliance. Tax audit has an important role in testing the compliance audit, which is, in turn, one of the most important sources of the measure of tax compliance and the sum of tax payable, so tax audit is expected to have a deterrent effect. This effect should ultimately increase tax compliance and maximize tax income (Irawan \& Budiono, 2015).

These factors are tax socialization, tax knowledge, tax awareness, tax service quality, tax sanction, and tax audit. By using meta-analysis approach, it is concluded that tax socialization, tax knowledge, tax awareness, tax service quality, tax sanction, and tax audit have both positive and significant relationship either for individual or institutional tax payer's compliance.

This research has two implications: theoretical and practical. Theoretically, this research enriches the literature and gives a conclusion for previous researches about tax compliance in Indonesia, which results were varied. Practically, this research gives a clearer picture to the government about factors (tax socialization, tax knowledge, tax awareness, tax service quality, tax sanction, and tax audit) that could be improved to increase tax compliance.

This research has three identified limitations. First, individuals as entities that represent the institutional taxpayers are not clearly identified. Second, this research only considers variable similarity, while it is possible that the same variable was measured by a different indicator. Third, the difference test was only done through the independent $\mathrm{t}$-test instead of the paired t-test, even though the test is intended to compare before and after taxation events.

\section{References}

Ananda, P. R. D., Kumadji, S., \& Husaini, A. (2015). Pengaruh sosialisasi perpajakan, tarif pajak, dan pemahaman perpajakan terhadap kepatuhan wajib pajak (studi pada UMKM yang terdaftar sebagai wajib pajak di Kantor Pelayanan Pajak Pratama Batu). Jurnal Perpajakan (JEJAK), 6.

Andinata, M. C. (2015). Analisis faktor-faktor yang mempengaruhi kepatuhan wajib pajak orang pribadi dalam membayar pajak (studi kasus pada Kantor Pelayanan Pajak Pratama Surabaya Rungkut. Jurnal Ilmiah Mahasiswa Universitas Surabaya, 4(2), 1-15.

Andyastuti, L., Topowijono, \& Husaini, A. (2013). Pengaruh penyuluhan, pelayanan, pemeriksaan dan sanksi terhadap penyampaian surat pemberitahuan orang pribadi (studi pada Kantor Pelayanan Pajak Pratama Malang Utara). Jurnal Administrasi Bisnis, 2(2).

Anjarini, K., Prasetyo, B. H., \& Irani, L. D. (2012). Analisis pelaksanaan pemeriksaan pajak dalam meningkatkan kepatuhan wajib pajak orang pribadi pada KPP Pratama Jakarta Sawah Besar Satu. Jurnal Akuntansi Perpajakan, 1-8.

Aprilina, K. R., Made, A., \& Dianawati, E. (2016). Pengaruh penagihan pajak, pemeriksaan pajak dan sanksi pajak terhadap tingkat kepatuhan wajib pajak di KPP Pratama Kepanjen. Jurnal Riset Mahasiswa Akuntansi, 4(2), 1-17.

Ariesta, C., \& Suryaningsih, R. (2013). Pengaruh kualitas pelayanan pajak dan penerapan sanksi pajak terhadap kepatuhan wajib pajak orang pribadi di KPP Pratama Kosambi. Ultima Accounting, 5(1), 36-54.

Asri, M., \& Wuri. (2009). Pengaruh kualitas pelayanan, biaya kepatuhan pajak, dan kesadaran wajib pajak pada kepatuhan pelaporan wajib pajak badan yang terdaftar di Kantor Pelayanan Pajak Madya Denpasar. Skripsi. Universitas Udayana.

Cooper, H. M. (1982). Scientific guidelines for conducting integrative research reviews. Reviews of Educational Research, 52, 291-302.

Dharma, M. T., \& Ariyanto, S. (2014). Analisis faktor-faktor yang mempengaruhi tingkat kepatuhan wajib pajak orang pribadi di lingkungan KPP Pratama Tigaraksa Tangerang. Binus Business Review, 5(2), 497-509.

Doli, D. S. L., \& Rusydi, M. K. (2014). Faktor-faktor yang mempengaruhi kepatuhan penyampaian surat pemberitahuan tahunan untuk wajib pajak badan (studi kasus pada Kantor Pelayanan Pajak Pratama Malang Selatan). Skripsi. Universitas Brawijaya.

Dyah, D. K. N., Handayani, S. R., \& Sulasmiyati, S. (2015). Pengaruh pengetahuan pajak dan kualitas pelayanan fiskus terhadap kepatuhan wajib pajak (studi pada wajib pajak badan di KPP Pratama Jember). Jurnal 
Mahasiswa Perpajakan, 5(1).

Eddy, E. P. S., \& Carolina, V. (2015). Pengaruh tingkat pengetahuan perpajakan wajib pajak orang pribadi terhadap kepatuhan wajib pajak pada Fakultas Ekonomi Universitas Kristen Maranatha. 2015, 7(1), 1-13.

Eny, N., Subroto, B., Sutrisno, \& Irianto, G. (2015). Meta-analysis: corporate governance dan manajemen laba di Indonesia. Paper presented at the Simposium Nasional Akuntansi 18, Medan.

Faisal, G. S. M. (2009). How To Be A Smarter Taxpayer. Jakarta: Grasindo.

Fanani, Z. (2014). Karakteristik perusahaan dan corporate governance terhadap manajemen laba: studi analisis meta. Jurnal Keuangan dan Perbankan, 18(2), 181-200.

Fraternesi. (2001). Studi empiris tentang pengaruh faktor-faktor yang melekat pada wajib pajak terhadap keberhasilan penerimaan pajak bumi dan bangunan di Kota Bengkulu. Tesis. Universitas Diponegoro.

García-Meca, E., \& Sánchez-Ballesta, J. P. (2009). Corporate governance and earnings management: a meta-analysis. Corporate Governance: An International Review, 17(5), 594-610.

Ghoni, H. A. (2012). Pengaruh motivasi dan pengetahuan wajib pajak terhadap kepatuhan wajib pajak daerah. Skripsi. Universitas Surabaya.

Ginting, R. P. (2015). Pengaruh pemeriksaan pajak terhadap kepatuhan wajib pajak (studi pada Kantor Pelayanan Pajak Madya Malang). Jurnal Mahasiswa Perpajakan, 6(1).

Hantoyo, S. S., Kertahadi, \& Handayani, S. R. (2016). Pengaruh penghindaran pajak dan sanksi pajak terhadap kepatuhan wajib pajak. Jurnal Perpajakan (JEJAK), 9(1), 1-7.

Herryanto, M., \& Toly, A. A. (2013). Pengaruh kesadaran wajib pajak, kegiatan sosialisasi perpajakan, dan pemeriksaan pajak terhadap penerimaan pajak penghasilan di KPP Pratama Surabaya Sawahan. Tax \& Accounting Review, 1(1), 124-135.

Hunter, J. E., \& Schmidt, F. L. (1990). Methods of Meta-analysis: Correcting Error and Bias in Research Findings. Beverly Hills CA: Sage.

Hutagaol, J. (2007). Perpajakan: Isu-isu Kontemporer. Yogyakarta: Graha Ilmu.

Ihsan, M. (2013). Pengaruh pengetahuan wajib pajak, penyuluhan pajak, kualitas pelayanan pajak dan pemeriksaan pajak terhadap kepatuhan wajib pajak badan di Kota Padang. Jurnal Akuntansi Perpajakan, 1(3), 1-31.

Ilyas, B. W., \& Burton, R. (2010). Hukum Pajak. Jakarta: Salemba Empat.

Indriyani, P. A., \& Sukartha, A. A. (2014). Tanggung jawab moral, kesadaran wajib pajak, sanksi perpajakan dan kualitas pelayanan pada kepatuhan pelaporan wajib pajak badan. E-Jurnal Akuntansi Universitas Udayana, 7(2), 431-443.

Irawan, B., \& Budiono, T. (2015). Analisis pemeriksaan pajak dalam rangka optimalisasi penerimaan negara di sektor perpajakan. Jurnal Ilmiah Ilmu Administrasi, 7(2).

Jatmiko, A. N. (2006). Pengaruh sikap wajib pajak pada pelaksanaan sanksi denda, pelayanan fiskus dan kesadaran perpajakan terhadap kepatuhan wajib pajak (studi empiris terhadap wajib pajak orang pribadi di Semarang). Tesis. Universitas Diponegoro.

Junita, I., \& Widiastuti, R. (2008). Pendekatan SERVQUAL dalam evaluasi kualitas pelayanan kantor pajak. Jurnal Studi Manajemen COMPETENCE, 2(1), 42-45.

Kristanty, N., Khairani, S., \& Fajriana, I. (2014). Pengaruh pengetahuan wajib pajak, tarif pajak, dan penyuluhan pajak terhadap tingkat kepatuhan wajib pajak badan di Kantor Pelayanan Pajak Madya Palembang. Skripsi. STIE MDP.

Kundalini, P. (2015). Pengaruh kesadaran wajib pajak dan pelayanan pegawai pajak terhadap kepatuhan wajib pajak pada KPP Pratama Kabupaten Temanggung Tahun 2015. Thesis. Universitas Negeri Yogyakarta.

Kusuma, K. C. (2016). Pengaruh kualitas pelayanan pajak, pemahaman peraturan perpajakan, serta sanksi perpajakan terhadap kepatuhan wajib pajak orang pribadi dalam membayar pajak tahun 2014 (studi kasus pada wajib pajak yang terdaftar pada KPP Wonosobo). Thesis. Universitas Negeri Yogyakarta.

Lerche, D. (1980). Efficiency of taxation in Indonesia. BIES, 16(1), 34-51.

Lyons, L. C. (1998). Meta-analysis: methods of accumulating results across research domains. Working Papers. 
George Washington University Medical Center.

Mahardika, I. G. P. (2015). Pengaruh Kualitas pelayanan dan sikap wajib pajak terhadap kepatuhan pelaporan wajib pajak orang pribadi di KPP Pratama Singaraja. Jurnal Jurusan Pendidikan Ekonomi, 5(1), 1-12.

Mandagi, C., Sabijono, H., \& Tirayoh, V. (2014). Pengaruh pemeriksaan pajak terhadap tingkat kepatuhan wajib pajak badan dalam memenuhi kewajiban perpajakannya pada KPP Pratama Manado. Jurnal EMBA, 2(3), 1665-1674.

Mardiasmo. (2003). Perpajakan. Yogyakarta: Andi Offset.

Meliala, A. N. K. S., \& Inasius, F. (2015). Pengaruh kualitas pelayanan fiskus dan sosialisasi perpajakan terhadap kepatuhan wajib pajak orang pribadi yang dikenakan PP No. 46 Tahun 2013. Thesis. Universitas Bina Nusantara.

Mir'atusholihah, Kumadji, S., \& Ismono, B. (2014). Pengaruh pengetahuan pajak, kualitas pelayanan fiskus dan tarif pajak terhadap kepatuhan wajib pajak (studi pada wajib pajak UMKM di KPP Pratama Malang Utara). Jurnal Mahasiswa Perpajakan, 3(1), 1-10.

Muliari, N. K., \& Setiawan, P. E. (2011). Pengaruh persepsi tentang sanksi perpajakan dan kesadaran wajib pajak pada kepatuhan pelaporan wajib pajak orang pribadi di Kantor Pelayanan Pajak Pratama Denpasar Timur. Jurnal Ilmiah Akuntansi dan Bisnis, 6(1), 1-23.

Mustikasari, E. (2007). Kajian empiris tentang kepatuhan wajib pajak badan di perusahaan industri pengolahan di Surabaya. Paper presented at the Simposium Nasional Akuntansi X.

Muzaki, A. F., \& Kusbandiyah, A. (2014). Pengaruh kesadaran WP, pelayanan fiskus dan sanksi perpajakan terhadap WP badan (studi kasus di KPP Kota Tegal). Kompartemen, $x(1), 1-9$.

Nasution, D. (2009). Sanksi ringan, bakal banyak yang telat serahkan SPT. Retrieved from www. pajakonline.com

Ngadiman, \& Huslin, D. (2015). Pengaruh sunset policy, tax amnesty, sanksi pajak terhadap kepatuhan wajib pajak. Jurnal Akuntansi Perpajakan, XIX(2), 225-241.

Nugroho. (2012). Faktor-faktor yang mempengaruhi kemauan untuk membayar pajak dengan variabel intervening. Thesis. Universitas Diponegoro.

Pamuji, A. R., Mukzam, M. D., \& Sudjana, N. (2014). Faktor-faktor yang mempengaruhi kepatuhan pemilik usaha mikro, kecil, dan menengah dalam memenuhi kewajiban perpajakan (studi pada wajib pajak pemilik UMKM di KPP Pratama Malang Selatan). Jurnal Mahasiswa Perpajakan, 3(1), 1-9.

Pandan, S. H. (2014). Pengaruh pengetahuan perpajakan, kualitas pelayanan, pemeriksaan dan kesadaran terhadap kepatuhan wajib pajak (studi empiris terhadap karyawan Kantor Badan Pusat Statistik Jember). Thesis. Universitas Jember.

Paramartha, I. P. I. P., \& Rasmini, N. K. (2015). Pengaruh kualitas pelayanan, pengetahuan dan sanksi perpajakan pada kepatuhan wajib pajak badan. E-Jurnal Akuntansi Universitas Udayana, 15(1), 641-666.

Pujiwidodo, D. (2016). Persepsi sanksi perpajakan terhadap kepatuhan wajib pajak orang pribadi. Jurnal Online Insan Akuntan, 1(1), 92-116.

Puri, K. A. (2014). Pengaruh kesadaran wajib pajak, pelayanan fiskus dan sanksi pajak terhadap kepatuhan wajib pajak orang pribadi yang melakukan kegiatan usaha dan pekerjaan bebas. Thesis. Universitas Muhamadiyah Surakarta.

Putra, R. R. R., Handayani, S. R., \& Topowijoyono. (2014). Pengaruh sanksi administrasi, sosialisasi perpajakan dan kesadaran wajib pajak terhadap kepatuhan penyampaian SPT tahunan wajib pajak orang pribadi (studi di Kantor Pelayanan Pajak Pratama Singosari, Kabupaten Malang). Jurnal e-Perpajakan, 1(1), 1-10.

Rahayu, S. K. (2010). Perpajakan Indonesia. Yogyakarta: Graha Ilmu.

Rajif, M. (2012). Pengaruh pemahaman, kualitas pelayanan, ketegasan sanksi perpajakan terhadap kepatuhan pajak pengusaha UKM di daerah Cirebon. Thesis. Universitas Gunadarma. Depok.

Risnawati. (2009). Pengaruh kualitas pelayanan pajak terhadap kepatuhan wajib pajak penghasilan orang pribadi. Jurnal Ekonomi dan Informatika.

Rohmawati, A. N., \& Rasmini, A. N. (2012). Pengaruh kesadaran, penyuluhan, pelayanan dan sanksi perpajakan pada kepatuhan wajib pajak orang pribadi. E-Journal Akuntansi, 1(2), 1-17. 
Sandi, N. B. (2010). Analisis pengaruh pelayanan, konsultasi, pengawasan account representative terhadap kepatuhan wajib pajak. Thesis. Universitas Islam Negeri Syarif Hidayahtullah.

Santoso, S. N., Susilo, H., \& Sulasmiyati, S. (2015). Pengaruh pengetahuan pajak, kesadaran wajib pajak, dan sanksi pajak terhadap kepatuhan wajib pajak (studi pada wajib pajak orang pribadi di Kantor Pelayanan Pajak Pratama Kepanjen). Jurnal Administrasi Bisnis - Perpajakan (JAB), 6(1).

Soemarso, S. R. (1998). Dampak reformasi perpajakan 1984 terhadap efisiensi sistem perpajakan indonesia. ekonomi dan keuangan perpajakan di Indonesia. Jurnal Ekonomi dan Keuangan Indonesia, XLVI(3), 333-368.

Sudrajat, A., \& Ompusunggu, A. P. (2015). Pemanfaatan teknologi informasi, sosialisasi pajak, pengetahuan perpajakan, dan kepatuhan pajak. Jurnal Riset Akuntansi dan Perpajakan, 2(2), 193-202.

Sukmawati, R. (2015). Pengaruh pelayanan, pengawasan dan konsultasi yang dilaksanakan oleh account representative serta pemeriksaan pajak terhadap kepatuhan wajib pajak badan yang terdaftar di KPP Madya Pekanbaru. Jurnal Online Mahasiswa (JOM) Bidang Ilmu Ekonomi, 2(2), 1-16.

Supriyati. (2012). Dampak motivasi dan pengetahuan perpajakan terhadap kepatuhan wajib pajak. Jurnal InFestasi, $8(1), 15-32$.

Suyapto, M., \& Lasmana, M. S. (2014). Analisis faktor-faktor yang mempengaruhi kepatuhan wajib pajak badan di Kantor Wilayah Direktorat Jenderal Pajak Jawa Timur I. Jurnal Ekonomi dan Bisnis, XXIV(2), 174-186.

Suyatmin. (2004). Pengaruh sikap wajib pajak terhadap kepatuhan wajib pajak dalam pembayaran pajak bumi dan bangunan (studi empiris di wilayah KP PBB Surakarta). Thesis. Universitas Diponegoro.

Tampubolon, K. P. B., \& Pratomo, D. (2015). Pengaruh account representative dan pengetahuan wajib pajak badan terhadap kepatuhan wajib pajak badan. Thesis. Universitas Telkom.

Tiraada, T. A. M. (2013). Kesadaran perpajakan, sanksi pajak, sikap fiskus terhadap kepatuhan wpop di Kabupaten Minahasa Selatan. Jurnal EMBA, 1(3), 999-1008.

Utami, T. D., \& Kardinal. (2013). Pengaruh kesadaran wajib pajak dan sanksi pajak terhadap kepatuhan wajib pajak orang pribadi pada KPP Seberang Ulu. Thesis. STIE MDP.

Warouw, J. Z. S., Sondakh, J. J., \& Walandouw, S. K. (2015). Pengaruh sosialisasi perpajakan dan sanksi perpajakan terhadap kepatuhan pelaporan spt tahunan wajib pajak badan (studi kasus pada KPP Pratama Manado dan KPP Pratama Bitung). Jurnal EMBA, 3(4), 585-592.

Widorini, S. G., \& Nugroho, J. P. (2014). Pengaruh pengetahuan, persepsi tentang tarif pajak dan penegakan hukum perpajakan terhadap kepatuhan wajib pajak orang pribadi di KPP Pratama Yogyakarta. Efektif Jurnal Bisnis dan Ekonomi, 5(1), 85-98.

Widyastuti, E. (2015). Pengaruh tingkat pemahaman wajib pajak, kualitas pelayanan, sanksi pajak dan lingkungan pajak terhadap tingkat kepatuhan wajib pajak orang pribadi (studi empiris pada KPP Pratama Solo). Thesis. Universitas Muhamadiyah Surakarta. 